\title{
Angka Keberhasilan Terapi Reperfusi pada Pasien ST Elevasi Miokard Infark
}

\author{
${ }^{1}$ Ermiati \\ ${ }^{2}$ Starry H. Rampengan \\ ${ }^{2}$ Victor F. F. Joseph
}

${ }^{1}$ Program Studi Pendidikan Dokter Fakultas Kedokteran Universitas Sam Ratulangi Manado

${ }^{2}$ Bagian Ilmu Penyakit Jantung dan Pembuluh Darah Fakultas Kedokteran

Universitas Sam Ratulangi Manado

Email: ermiati19091997@gmail.com

\begin{abstract}
ST-Elevation Myocardial Infarction (STEMI) is a kind of acute myocardial infarctions (AMI) with a high rate of mortality. Patients with STEMI are usually treated with reperfusion therapy consisting of primary percutaneous coronary intervention (primary PCI) and fibrinolytic therapy. This study was aimed to determine the success rate of reperfusion therapy in patients with STEMI at Prof. Dr. R. D Kandou Hospital Manado from January to December 2016. This was a descriptive observational study with a retrospective approach. Samples were patients with STEMI treated with reperfusion therapy at Prof. Dr. R. D Kandou Hospital Manado from January to December 2016, obtained by using consecutive sampling method. There were 73 patients in this study consisted of $82.2 \%$ of males and $17.8 \%$ of females. Most patients were $>60$ years old; $39.0 \%$ treated with primary PCI and $43.8 \%$ with fibrinolytic therapy. According to duration of therapy administration, most primary PCI were given at $>90$ minutes $(80.5 \%)$ and fibrinolytic therapy at $>30$ minutes $(75 \%)$. The success rate of primary PCI was higher in patients treated at $\leq 90$ minutes (100\%) compared to patients treated at $>90$ minutes. Moreover, the success rate of fibrinolytic therapy was higher in patients treated at $\leq 30$ minutes $(100 \%)$ compared to patients treated at $>30$ minutes $(75 \%)$. Ventricular tachycardia (34.6\%) was the most common type of reperfusion arrhythmia. Conclusion: The success rate of reperfusion therapy (primary PCI and fibrinolytic) in STEMI patients was higher if it was administered according to the optimum recommendations and targets.
\end{abstract}

Keywords: STEMI, success rate of reperfusion therapy

\begin{abstract}
Abstrak: ST elevasi miokard infark (STEMI) merupakan jenis infark miokard akut (IMA) dengan mortalitas yang tinggi. Penatalaksanaan pasien STEMI dilakukan dengan terapi reperfusi yang terdiri primary percutaneous coronary intervention (primary PCI) dan fibrinolitik. Penelitian ini bertujuan untuk mengetahui angka keberhasilan terapi reperfusi pada pasien STEMI di RSUP Prof. Dr. R. D. Kandou Manado periode Januari-Desember 2016. Jenis penelitian ialah deskriptif observasional dengan pendekatan retrospektif. Sampel penelitian ialah pasien STEMI yang menerima terapi reperfusi, dirawat di RSUP Prof. Dr. R. D. Kandou Manado periode Januari-Desember 2016, yang diperoleh dengan teknik consecutive sampling. Dari total 73 pasien STEMI didapatkan pasien berjenis kelamin laki-laki $(82,2 \%)$ lebih banyak dibandingkan perempuan $(17,8 \%)$. Kelompok usia terbanyak ialah $>60$ tahun; 39,0\% untuk terapi primary PCI dan $43,8 \%$ untuk terapi fibrinolitik. Waktu dilakukannya terapi reperfusi terbanyak dengan waktu terapi $>90$ menit untuk terapi primary PCI $(80,5 \%)$ dan $>30$ menit (75\%) untuk terapi fibrinolitik. Angka keberhasilan terapi primary PCI $\leq 90$ menit lebih tinggi (100\%) dibandingkan dengan terapi primary PCI $>90$ menit $(96,6 \%)$, dan angka keberhasilan terapi fibrinolitik $\leq 30$ menit lebih tinggi $(100 \%)$ dibandingkan dengan terapi fibrinolitik $>30$ menit $(75 \%)$. Jenis aritmia reperfusi ditemukan terbanyak ialah aritmia ventrikel takikardi
\end{abstract}


(34,6\%). Simpulan: Angka keberhasilan terapi reperfusi (primary PCI dan fibrinolitik) pada pasien STEMI lebih tinggi jika dilakukan tepat waktu sesuai dengan sasaran terapi optimal.

Kata kunci: STEMI, angka keberhsilan terapi reperfusi.

Penyakit jantung koroner (PJK) merupakan salah satu penyakit kardiovaskuler utama yang sering menyebabkan kematian di dunia. Salah satu jenis PJK ialah infark miokard akut (IMA) yang juga merupakan penyebab utama kematian di dunia dengan prevalensi sebanyak $12,2 \%$ atau sekitar 7,2 juta. Berdasarkan data dari American Heart Association (AHA) tahun 2015, angka kematian akibat penyakit kardiovaskuler di Amerika Serikat sebesar 31,3\%. Data penelitian Atherosclerosis Risk in Communities Study (ARIC) dan Cardiovascular Health Study (CHS) dari National Heart, Lung and Blood Institute (NHLBI) 2011 memperlihatkan 785.000 orang Amerika akan mengalami serangan IMA untuk pertama kalinya dan 470.000 akan mengalami infark berulang. ${ }^{1,2}$

Faktor-faktor yang dapat menyebabkan IMA antara lain diabetes melitus, dislipidemia, merokok, hipertensi, dan riwayat STEMI dalam keluarga. ${ }^{3}$ Infark miokard akut terdiri dari ST elevasi miokard infark (STEMI) dan non ST elevasi miokard infark (NSTEMI). Pasien IMA terutama dengan STEMI memiliki angka mortalitas tinggi, khususnya dalam 2 jam pertama setelah serangan, sehingga memerlukan pemeriksaan yang cepat untuk mendiagnosis dini agar dapat segera dilakukan penanganan yang cepat untuk mencegah kematian. ${ }^{1,3}$

Penatalaksanaan STEMI ialah terapi reperfusi yang terdiri dari terapi fibrinoltik dan primary percutaneous coronary intervention (primary PCI). Terapi reperfusi fibrinolitik dan primary PCI yang diberikan tepat indikasi dan waktu $<12$ jam dapat menurunkan kejadian komplikasi dan kematian, terutama jika diberikan $\leq 30$ menit untuk fibrinolitik dan $\leq 90$ menit untuk primary PCI sejak pasien masuk ke rumah sakit. ${ }^{1,4}$

Menurut penelitian pada tahun 2015 di RSUD Moewardi ${ }^{5}$ didapatkan 18 dari 25 pasien mengalami perubahan ST elevasi
$>70 \%$ terhadap terapi fibrinolitik dan menurut Buller et al. ${ }^{6}$ tingkat keberhasilan terapi primary PCI mencapai 99\%, sedangkan untuk terapi fibrinolitik dapat menurunkan tingkat kematian sebesar 20-30\%.

Penelitian ini bertujuan untuk mengetahui angka keberhasilan terapi reperfusi (primary PCI dan fibrinolitik) pada pasien STEMI di RSUP Prof. Dr. R. D. Kandou Manado periode Januari-Desember 2016. Diharapkan hasil penelitian ini dapat menambah wawasan, pengetahuan, memberikan informasi, dan dapat menjadi bahan masukkan bagi instalasi pendidikan mengenai tingkat keberhasilan terapi reperfusi (primary PCI dan fibrinolitik) pada pasien STEMI.

\section{METODE PENELITIAN}

Jenis penelitian ini ialah deskriptif observasional dengan pendekatan retrospektif menggunakan data sekunder dari rekam medik pasien STEMI yang mendapatkan terapi reperfusi (primary PCI dan fibrinolitik) yang dirawat di RSUP Prof. Dr. R. D. Kandou Manado selama Januari Desember 2016. Pada penelitian ini didapatkan sampel sebanyak 41 pasien untuk terapi primary PCI dan 32 pasien untuk terapi fibrinolitik. Pengolahan data dilakukan secara manual dan komputerisasi.

\section{HASIL PENELITIAN}

Berdasarkan hasil penelitian yang dilakukan didapatkan total pasien STEMI sebanyak 120 pasien yang terdiri dari 77 kandidat untuk terapi primary PCI, dan 43 kandidat untuk terapi fibrinolitik. Dari total kandidat untuk terapi primary PCI, yang memenuhi kriteria inklusi sebanyak 41 pasien; 36 pasien dieksklusi, yaitu 26 pasien dengan onset gejala $>12$ jam dan 10 pasien memiliki data yang tidak dapat dianalisis (DVD angiografi tidak terbaca). Dari total kandidat untuk terapi fibrinolitik didapatkan 32 pasien yang memenuhi kriteria inklusi, 
dan 11 pasien dieksklusi karena memiliki onset gejala $>12$ jam.

Dari hasil penelitian didapatkan pasien laki-laki sebanyak 60 orang $(82,2 \%)$ dan pasien perempuan sebanyak 13 orang $(17,8 \%)$ (Tabel 1).

Tabel 1. Distribusi pasien STEMI yang mendapat terapi reperfusi berdasarkan kelompok jenis kelamin

\begin{tabular}{ccc}
\hline Jenis kelamin & $\begin{array}{c}\text { Jumlah } \\
(\mathbf{N})\end{array}$ & $\begin{array}{c}\text { Persentase } \\
(\mathbf{\%})\end{array}$ \\
\hline Laki-laki & 60 & $82,2 \%$ \\
Perempuan & 13 & $17,8 \%$ \\
Jumlah & 73 & $100 \%$ \\
\hline
\end{tabular}

Pada primary PCI terdapat pasien lakilaki sebanyak 35 orang $(85,4 \%)$ dan perempuan sebanyak 6 orang $(14,6 \%)$ (Tabel 2).

Tabel 2. Distribusi pasien berdasarkan kelompok jenis kelamin pada primary PCI

\begin{tabular}{ccc}
\hline Jenis kelamin & $\begin{array}{c}\text { Jumlah } \\
(\mathbf{N})\end{array}$ & $\begin{array}{c}\text { Persentase } \\
(\mathbf{\%})\end{array}$ \\
\hline Laki-Laki & 35 & $85,4 \%$ \\
Perempuan & 6 & $14,6 \%$ \\
Jumlah & 41 & $100 \%$ \\
\hline
\end{tabular}

Sebagian besar pasien berada pada kelompok usia > 60 tahun sebanyak 16 orang (39,0\%), diikuti kelompok usia 50-59 tahun sebanyak 13 orang $(31,7 \%)$, kelompok usia 40-49 tahun sebanyak 10 orang $(24,4 \%)$, dan kelompok usia <40 tahun sebanyak 2 orang $(4,9 \%)$ (Tabel 3).
Tabel 3. Distribusi pasien berdasarkan kelompok usia pada primary PCI

\begin{tabular}{ccc}
\hline $\begin{array}{c}\text { Usia } \\
\text { (tahun) }\end{array}$ & $\begin{array}{c}\text { Jumlah } \\
(\mathbf{N})\end{array}$ & $\begin{array}{c}\text { Persentase } \\
(\boldsymbol{\%})\end{array}$ \\
\hline$<40$ & 2 & $4,9 \%$ \\
$40-49$ & 10 & $24,4 \%$ \\
$50-59$ & 13 & $31,7 \%$ \\
$>60$ & 16 & $39,0 \%$ \\
Jumlah & 41 & $100 \%$ \\
\hline
\end{tabular}

Hasil penelitian menunjukkan bahwa jumlah pasien terbanyak ialah dengan waktu terapi $>90$ menit yaitu sebanyak 33 orang $(80,5 \%)$, sedangkan yang dengan waktu terapi $\leq 90$ menit sebanyak 8 orang $(19,5 \%)$ (Tabel 4).

Tabel 4. Distribusi pasien berdasarkan waktu terapi primary $\mathrm{PCI}$

\begin{tabular}{ccc}
\hline $\begin{array}{c}\text { Waktu terapi } \\
\text { primary PCI }\end{array}$ & $\begin{array}{c}\text { Jumlah } \\
(\mathbf{N})\end{array}$ & $\begin{array}{c}\text { Persentase } \\
(\%)\end{array}$ \\
\hline > 90 menit & 8 & $19,5 \%$ \\
$>90$ menit & 33 & $80,5 \%$ \\
Jumlah & 41 & $100 \%$ \\
\hline
\end{tabular}

Hasil penelitian menunjukkan bahwa angka keberhasilan terapi primary PCI pada pasien ST elevasi yang mendapatkan terapi tepat waktu yaitu $\leq 90$ menit sebesar $100 \%$ sedangkan angka keberhasilan terapi primary PCI pada pasien ST elevasi yang mendapatkan terapi $>90$ menit sebesar 96,6\% (Tabel 5).

Tabel 5. Angka keberhasilan terapi primary PCI $\leq 90$ menit dan $>90$ menit

\begin{tabular}{lcccc}
\hline Waktu terapi & \multicolumn{2}{c}{ Parameter / Kriteria keberhasilan } & Persentase \\
& $\begin{array}{c}\text { Diameter } \\
\text { stenosis }<\mathbf{1 0 \%}\end{array}$ & $\begin{array}{c}\text { Tanpa } \\
\text { komplikasi }\end{array}$ & $\begin{array}{c}\text { Hilangnya } \\
\text { gejala STEMI }\end{array}$ & $(\boldsymbol{\%})$ \\
\hline $\begin{array}{l}\leq 90 \text { menit } \\
(\mathrm{n}=8)\end{array}$ & 8 & 8 & 8 & $100 \%$ \\
$\begin{array}{l}>90 \text { menit } \\
(\mathrm{n}=33)\end{array}$ & 33 & 32 & 33 & $96,6 \%$ \\
\hline
\end{tabular}

Hasil penelitian memperlihatkan bahwa terdapat 25 orang laki-laki $(78,1 \%)$ dan 7 orang perempuan $(21,9 \%)$ yang mendapatkan terapi fibrinolitik (Tabel 6). 
Tabel 6. Distribusi pasien berdasarkan kelompok jenis kelamin pada fibrinolitik

\begin{tabular}{ccc}
\hline Jenis kelamin & $\begin{array}{c}\text { Jumlah } \\
(\mathbf{N})\end{array}$ & $\begin{array}{c}\text { Persentase } \\
(\boldsymbol{\%})\end{array}$ \\
\hline Laki-Laki & 25 & $78,1 \%$ \\
Perempuan & 7 & $21,9 \%$ \\
Jumlah & 32 & $100 \%$ \\
\hline
\end{tabular}

Sebagian besar pasien berada pada kelompok usia $>60$ tahun yaitu sebanyak 14 orang $(43,8 \%)$, diikuti kelompok usia 50-59 tahun sebanyak 12 orang $(37,5 \%)$, kelompok usia 40-49 tahun sebanyak 5 orang $(15,6 \%)$, dan kelompok usia $<40$ tahun sebanyak 1 orang $(3,1 \%)$ (Tabel 7$)$.

Tabel 7. Distribusi pasien berdasarkan kelompok usia pada fibrinolitik

\begin{tabular}{ccc}
\hline Usia (tahun) & $\begin{array}{c}\text { Jumlah } \\
(\mathbf{N})\end{array}$ & $\begin{array}{c}\text { Persentase } \\
(\boldsymbol{\%})\end{array}$ \\
\hline$<40$ & 1 & $3,1 \%$ \\
$40-49$ & 5 & $15,6 \%$ \\
$50-59$ & 12 & $37,5 \%$ \\
$>60$ & 14 & $43,8 \%$ \\
Jumlah & 32 & $100 \%$ \\
\hline
\end{tabular}

Jumlah pasien terbanyak ialah dengan waktu terapi $>30$ menit yaitu sebanyak 24 orang $(75 \%)$, sedangkan waktu terapi $\leq 30$ menit sebanyak 8 orang (25\%) (Tabel 8).

Tabel 8. Distribusi pasien berdasarkan kelompok waktu terapi fibrinolitik

\begin{tabular}{ccc}
\hline $\begin{array}{c}\text { Waktu terapi } \\
\text { fibrinolitik }\end{array}$ & $\begin{array}{c}\text { Jumlah } \\
(\mathbf{N})\end{array}$ & $\begin{array}{c}\text { Persentase } \\
(\%)\end{array}$ \\
\hline$\leq 30$ menit & 8 & $25 \%$ \\
$>30$ menit & 24 & $75 \%$ \\
Jumlah & 32 & $100 \%$ \\
\hline
\end{tabular}

Dari hasil penelitian didapatkan bahwa pasien yang mendapatkan terapi fibrinolitik tepat waktu yaitu $\leq 30$ menit, memiliki angka keberhasilan $100 \%$, sedangkan angka keberhasilan pasien dengan terapi fibrinolitik dan waktu pemberian $>30$ menit yaitu sebesar 75\% (Tabel 9).

Dari hasil penelitian didapatkan aritmia reperfusi yang sering muncul setelah terapi fibrinolitik yaitu ventrikel takikardi (34,6\%), atrial fibrilasi (30,8\%), accelerated idioventricular rhytm (AIVR) (26,9\%), dan ventrikel fibrilasi $(7,7 \%)$ (Tabel 10).

Tabel 9. Angka keberhasilan terapi fibrinolitik $\leq 30$ menit dan $>30$ menit

\begin{tabular}{|c|c|c|c|c|}
\hline \multirow[b]{2}{*}{ Waktu terapi } & \multicolumn{3}{|c|}{ Parameter / Kriteria keberhasilan } & \multirow{2}{*}{$\begin{array}{c}\text { Persentase } \\
(\%)\end{array}$} \\
\hline & $\begin{array}{c}\text { Nyeri } \\
\text { berkurang }\end{array}$ & $\begin{array}{c}\text { Turunnya ST- } \\
\text { elevasi }>50 \%\end{array}$ & $\begin{array}{c}\text { Aritmia } \\
\text { reperfusi }\end{array}$ & \\
\hline $\begin{array}{c}\leq 30 \text { menit } \\
(\mathrm{n}=8)\end{array}$ & $2=0$ & 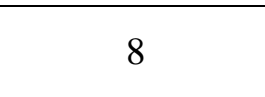 & 8 & $100 \%$ \\
\hline $\begin{array}{c}>30 \text { menit } \\
(\mathrm{n}=24)\end{array}$ & 18 & 18 & 18 & $75 \%$ \\
\hline
\end{tabular}

Tabel 10. Distribusi pasien berdasarkan jenis aritmia reperfusi

\begin{tabular}{lcc}
\hline Jenis aritmia & $\begin{array}{c}\text { Jumlah } \\
(\mathbf{N})\end{array}$ & $\begin{array}{c}\text { Persentase } \\
(\boldsymbol{\%})\end{array}$ \\
\hline Accelerated idioventricular rhytm (AIVR) & 7 & $26,9 \%$ \\
Ventrikel takikardi & 9 & $34,6 \%$ \\
Ventrikel fibrilasi & 2 & $7,7 \%$ \\
Atrial fibrilasi & 8 & $30,8 \%$ \\
Jumlah & 26 & $100 \%$ \\
\hline
\end{tabular}

\section{BAHASAN}

Berdasarkan hasil penelitian didapatkan bahwa penderita STEMI terbanyak pada jenis kelamin laki-laki yaitu sebanyak 60 orang $(82,2 \%)$ sedangkan jenis kelamin perempuan sebanyak 13 orang $(17,8 \%)$. 
Hasil penelitian ini selaras dengan hasil yang dilaporkan oleh Ilhami et al. ${ }^{7}$ tahun 2015 yang mendapatkan bahwa insiden STEMI lebih tinggi pada laki-laki dibandingkan pada perempuan. Hal ini dikaitkan dengan adanya hormon estrogen pada perempuan yang memiliki sifat proteksi sehingga perempuan cenderung lebih terlindungi dari kejadian kardiovaskular. Hal serupa juga dikemukakan oleh Sonia et al. dalam sebuah studi INTERHEART yang melaporkan bahwa laki-laki lebih banyak mengalami infark miokard $(74,9 \%)$ dibandingkan dengan perempuan $(25,1 \%){ }^{8}$

Berdasarkan distribusi usia, pada penelitian ini didapatkan kelompok usia terbanyak untuk terapi primary PCI berada pada kelompok usia >60 tahun sebanyak 16 orang (39,0\%), diikuti kelompok usia 50-59 tahun sebanyak 13 orang $(31,7 \%)$, kelompok usia 40-49 tahun sebanyak 10 orang $(24,4 \%)$, dan kelompok usia <40 tahun sebanyak 2 orang $(4,9 \%)$. Untuk terapi fibrinolitik, didapatkan kelompok usia terbanyak yaitu usia $>60$ tahun, dengan jumlah 14 orang $(43,8 \%)$, diikuti kelompok usia 50-59 tahun sebanyak 12 orang (37,5\%), kelompok usia 40-49 tahun sebanyak 5 orang $(15,6 \%)$, dan kelompok usia <40 tahun sebanyak 1 orang $(3,1 \%)$. Hasil ini sejalan dengan penelitian yang dilakukan oleh Wagyu ${ }^{9}$ pada tahun 2011. Hal ini terjadi oleh karena elastisitas pembuluh darah yang semakin menurun. Pembuluh darah akan menjadi kaku seiring dengan bertambahnya usia oleh karena terjadi pengapuran pada dinding pembuluh darah dan adanya tumpukan kolesterol pada dinding bagian dalam pembuluh darah yang terjadi karena kerusakan endotel (disfungsi endotel). ${ }^{9}$ Kerusakan endotel ini akan menyebabkan terbentuknya celah pada permukaan endotel tersebut sehingga kolesterol atau lipoprotein akan masuk dan memicu terjadinya reaksi inflamasi, Kolesterol atau lipoprotein yang masuk ke dalam pembuluh darah tersebut akan dianggap sebagai benda asing, sehingga makrofag berusaha untuk menghancurkannya dengan cara membungkusnya, dan pada akhirnya, makrofag tersebut penuh dengan lemak yang disebut foam cell yang akan membentuk plak aterosklerosis. Plak yang terbentuk akan menjadi tidak stabil dan dapat mengalami ruptur yang akan memicu aktivasi trombosit untuk memro-duksi dan melepaskan tromboksan A2. Aktivitas trombosit juga akan memicu terjadinya agregasi platelet dan mengaktivasi faktor VII dan X sehingga mengonversi protombin menjadi trombin dan fibrinogen menjadi fibrin. Pada kaskade koagulasi akan terbentuk thrombus yang akan menyebabkan oklusi pembuluh darah dan penurunan aliran darah secara mendadak yang akan memicu terjadinya STEMI. ${ }^{9,10}$

Berdasarkan waktu dilakukannya terapi reperfusi pada pasien STEMI didapatkan hasil bahwa jumlah pasien terbanyak pada terapi primary PCI ialah dengan waktu terapi >90 menit sebanyak 33 orang $(80,5 \%)$, sedangkan waktu terapi $\leq 90$ menit sebanyak 8 orang $(19,5 \%)$. Pada terapi fibrinolitik, yang terbanyak yaitu dengan waktu terapi $>30$ menit berjumlah 24 orang $(75 \%)$, dan waktu terapi $\leq 30$ menit berjumlah 8 orang (25\%). Hasil penelitian ini selaras dengan penelitian yang dilakukan Devi ${ }^{11}$ pada tahun 2010. Hal ini menunjukkan bahwa pelaksanaan terapi reperfusi $\leq 90$ menit untuk primary PCI dan $\leq 30$ menit untuk terapi fibrinolitik pada pasien STEMI masih kurang dilaksanakan. Keadaan ini disebabkan banyaknya faktor yang memengaruhi pelaksanaan terapi optimal tersebut, antara lain terjadinya kemacetan lalu lintas, dan jauhnya jarak rumah pasien dengan rumah sakit, sehingga mengakibatkan waktu door to balloon dan door to needle menjadi lebih pendek saat tiba di rumah sakit. ${ }^{11}$

Hasil penelitian yang dilakukan oleh Pratiwi et al. ${ }^{12}$ menyatakan bahwa sasaran optimal untuk terapi reperfusi belum sepenuhnya dilakukan tepat waktu karena adanya beberapa alasan seperti ketidaktahuan pasien mengenai penyakitnya, tingkat pengetahuan pasien yang kurang sehingga hanya menganggapnya sebagai penyakit biasa (paling sering masuk angin), tidak adanya fasilitas EKG pada pelayanan 
kesehatan tingkat pertama, ketidakpastian diagnosis (terutama untuk penggunaan terapi fibrinolitik), kurang tanggapnya staf medis terhadap pasien, perlunya evaluasi dan penanganan terhadap keadaan lain yang mengancam jiwa (misalnya gagal napas), atau penundaan terkait dengan pasien/ keluarga yang membutuhkan waktu untuk mengambil keputusan dalam pemberian terapi reperfusi.

Dari hasil penelitian, didapatkan bahwa pasien dengan pemberian terapi tepat waktu yaitu $\leq 90$ menit untuk terapi primary PCI sebanyak 8 orang $(19,5 \%)$ dan untuk terapi fibrinolitik dengan terapi $\leq 30$ menit sebanyak 8 orang $(25 \%)$ memiliki angka keberhasilan yang relatif tinggi dan sukses yaitu sebesar $100 \%$ untuk kedua terapi, sedangkan pemberian terapi $>90$ menit untuk terapi primary PCI pada 33 orang pasien $(80,5 \%)$ memiliki angka keberhasilan sebesar 96,6\%. Hal ini dikarenakan satu pasien dengan terapi primary PCI dengan pelaksanaan terapi $>90$ menit mengalami komplikasi yaitu terjadi apnea dan aritmia (ventrikel takikardi) setelah prosedur primary PCI. Terapi fibrinolitik dengan pemberian terapi $>30$ menit pada 24 pasien $(75 \%)$ memiliki angka keberhasilan yang relatif lebih rendah yaitu $75 \%$, ditandai dengan adanya 6 orang pasien yang memiliki nyeri yang tidak berkurang, penurunan ST elevasi yang tidak mencapai $50 \%$, dan tidak adanya aritmia reperfusi meskipun telah diberikan terapi fibrinolitik. Hal ini sesuai dengan penelitian yang dilakukan oleh Buller et al. ${ }^{6}$ dan Giuseppe De Lucca ${ }^{13}$ yang mengatakan bahwa semakin cepat terapi reperfusi dilakukan maka semakin besar peluang pasien untuk sembuh dan setiap penundaan terapi reperfusi pada pasien STEMI akan memengaruhi besarnya kematian dalam 1 tahun. Selain itu, angka keberhasilan terapi fibrinolitik juga akan semakin rendah bahkan bisa gagal terutama untuk terapi fibrinolitik jika pasien memiliki onset gejala $>12$ jam. Hal ini dikarenakan setelah 12 jam oklusi, progresifitas kerusakan sel semakin meningkat dan menjadi irreversibel. ${ }^{6,13}$

Berdasarkan hasil penelitian yang dilakukan, didapatkan aritmia reperfusi yang sering muncul setelah terapi fibrinolitik yaitu ventrikel takikardi (34,6\%), diikuti atrial fibrilasi (30,8\%), AIVR $(26,9 \%)$, dan ventrikel fibrilasi $(7,7 \%)$. Hal ini sesuai dengan penelitian Tatli et al. ${ }^{14} \mathrm{di}$ Turki yang menyatakan bahwa aritmia reperfusi yang sering muncul setelah terapi fibrinolitik ialah ventrikel takikardi, atrial fibrilasi, AIVR, ventrikel takikardi, dan kontraksi ventrikel prematur. Penelitian yang dilakukan oleh Gibson et al. ${ }^{15}$ melaporkan bahwa aritmia reperfusi yang muncul terbanyak setelah pemberian terapi fibrinolitik dari 3491 pasien ialah ventrikel takikardi.

\section{SIMPULAN}

Berdasarkan hasil penelitian terhadap pasien ST elevasi miokard infark (STEMI) di RSUP Prof. Dr. R. D. Kandou periode Januari-Desember 2016 dapat disimpulkan bahwa angka keberhasilan terapi reperfusi relatif tinggi dan sukses yaitu mencapai $100 \%$ untuk terapi primary PCI dan fibrinolitik yang diberikan tepat waktu yaitu $\leq 30$ menit untuk fibrinolitik dan $\leq 90$ menit untuk primary PCI sedangkan angka keberhasilan terapi reperfusi dengan waktu terapi $>30$ menit untuk fibrinolitik dan $>90$ menit untuk primary PCI lebih rendah yaitu $75 \%$ untuk terapi fibrinoltik dan 96,6\% untuk terapi primary PCI.

\section{SARAN}

1. Diharapkan dapat dilakukan penelitian analitik lebih lanjut mengenai besarnya angka keberhasilan terapi reperfusi pada pasien STEMI di RSUP Prof. Dr. R. D. Kandou Manado.

2. Diharapkan untuk kedepannya dalam penulisan data pada rekam medik bisa lebih dilengkapi dan diperjelas, sehingga peneliti bisa lebih memahami dan mendapatkan informasi yang lebih akurat.

\section{DAFTAR PUSTAKA}

1. Shofiyah L. Infark miokard akut [Skripsi]. Surakarta: Universitas Sebelas Maret, 2015. 
2. American Heart Association Heart Disease and Stroke Statistics 2011. Available from: http://circ.ahajournals.org/ content/123/4/e18.full

3. Safitri ES. ST Elevasi Miokard Infark (STEMI) anteroseptal pada pasien dengan faktor resiko kebiasaan merokok menahun dan tingginya kadar kolesterol dalam darah [Skripsi]. Lampung: Universitas Lampung; 2015.

4. Sofyan A, Itsnaini. Perbandingan clinical outcome pasien infark miokard akut STElevasi (STEMI) pasca terapi intevensi koroner perkutan primer dan terapi fibrinolitik di RSUP Dr. Kariadi Semarang [Skripsi]. Semarang: Universitas Muhammadiyah Semarang; 2016.

5. Anis S, Sumardjo, Masyita DL. Perbedaan antara terapi fibrinolitik dan heparnisasi terhadap perubahan ST elevasi pada penderita infark miokard akut di RSUD Moewardi [Skripsi]. Surakarta: Universitas Muhammadiyah; 2015.

6. Buller CE, Rankin JM, Hochman JS. Percutaneous coronary intervention in the occluded artery trial: procedural success, hazard, and outcomes over 5 years. Am Heart J. 2010;158(3):408.

7. Ilhami YR, Syukri M, Rasyid HE. Perubahan durasi QRS dan skor QRS Selvester pada pasien infark miokard akut dengan ST elevasi segmen ST yang menjalani intervensi koroner perkutan primer [Tesis]. Padang: Universitas Andalas; 2015.

8. Yunyun W, Tong L, Yingwu L, Bojiang L, Yu W, Xiaomin H, et al. Analysis of risk factors of ST-segment elevation myocardial infarction in young patients. licensee BioMed Central Ltd. 2014. Available from: https://bmccardiovascdisord.biomedce ntral.com/articles/10.1186/1471-226114-179.

9. Wagyu EA. Gambaran pasien infark miokard dengan ST elevasi (STEMI) yang dirawat di BLU RSUP. Prof. DR. R. D. Kandou Manado periode Januari 2010 sampai Desember 2010 [Skripsi]. Manado: Universitas Sam Ratulangi; 2011.

10. Devi D. Management pasien ST Elevasi Miokardial Infark (STEMI) [Skripsi]. Banda Aceh: Universitas Syiah Kuala; 2017.

11. Daudeline D, Assaad SJ, Kwong M, Restuccia MC, Porcaro WA, Ruthazer R, et al. Improving use of prehospital 12-lead ECG for early identification and treatment of scute coronary syndrome and ST-Elevation Myocardial Infraction. Circ Cardiovasc Qual Outcomes. 2010;3:316-23.

12. Pratiwi I, Rifqi S, Maharani N. Komplikasi pada pasien infark miokard akut ST elevasi (STEMI) yang mendapat maupun tidak mendapat terapi reperfusi [Skripsi]. Semarang: Universitas Diponegoro; 2013.

13. De Giuseppe L. Time delay to treatment and mortality in primary angioplasty for acute myocardial infarction. American Heart Association, Inc. 2004.

14. Tatli E, Guray A, Buturak A, Yilmaztepe M, Meryem A. Arrhythmias following revascularization procedures in the course of acute myocardial infraction: Are they indicators of reperfusion or ongoing ischemia? Hindawi Publishing Corporation. Turkey: 2013.

15. Gibson CM, Pride YB, Buros JL, Lord E, Shui A, Murphy SA, et al. TIMI Study Grup Association of impaired thrombolysis in myocardial infraction myocardial perfusion grade with ventricular tachycardia and ventricular fibrillation following fibrinolytic terapy for ST-Segmen elevation myocardian infraction. J Am Coll Cardiol. 2008;51(5):546-51. 